\title{
Soil conservation in the 21st century: why we need smart agricultural intensification
}

\author{
Gerard Govers $^{1}$, Roel Merckx ${ }^{1}$, Bas van Wesemael ${ }^{2}$, and Kristof Van Oost ${ }^{2}$ \\ ${ }^{1}$ KU Leuven, Department of Earth and Environmental Sciences, Celestijnenlaan 200E, 3001 Leuven, Belgium \\ ${ }^{2}$ Université Catholique de Louvain, Earth and Life Institute, 3 Place Louis Pasteur, \\ 1348 Louvain-la-Neuve, Belgium \\ Correspondence to: Gerard Govers (gerard.govers@ees.kuleuven.be)
}

Received: 19 May 2016 - Discussion started: 28 July 2016

Revised: 4 January 2017 - Accepted: 13 January 2017 - Published: 1 March 2017

\begin{abstract}
Soil erosion severely threatens the soil resource and the sustainability of agriculture. After decades of research, this problem still persists, despite the fact that adequate technical solutions now exist for most situations. This begs the question as to why soil conservation is not more rapidly and more generally implemented. Studies show that the implementation of soil conservation measures depends on a multitude of factors but it is also clear that rapid change in agricultural systems only happens when a clear economic incentive is present for the farmer. Conservation measures are often more or less cost-neutral, which explains why they are often less generally adopted than expected. This needs to be accounted for when developing a strategy on how we may achieve effective soil conservation in the Global South, where agriculture will fundamentally change in the next century. In this paper we argue that smart intensification is a necessary component of such a strategy. Smart intensification will not only allow for soil conservation to be made more economical, but will also allow for significant gains to be made in terms of soil organic carbon storage, water efficiency and biodiversity, while at the same time lowering the overall erosion risk. While smart intensification as such will not lead to adequate soil conservation, it will facilitate it and, at the same time, allow for the farmers of the Global South to be offered a more viable future.
\end{abstract}

\section{Introduction}

The terrestrial land surface provides critical services to humanity and this is largely possible because soils are present. Humanity uses ca. 15 million $\mathrm{km}^{2}$ of the total Earth's surface as arable farmland (Ramankutty et al., 2008). Besides this, ca. 30 million $\mathrm{km}^{2}$ is being used as grazing lands: on all these lands, plants grow which are either directly (as food) or indirectly (as feed, fibre or fuel) used by humans for nutrition and a large range of economic activities. Agricultural areas, especially areas used as arable land, have often been selected because they have soils that make them suitable for agriculture. But it is not only the soils on agricultural land that provide humanity with essential services. Also, on nonagricultural land soils provide the necessary rooting space for plants, store the water necessary for their growth and provide nutrients in forms that plants can access. On both agricul- tural and non-agricultural land, soils are host to an important fauna whose diversity is, by some measures, larger than that of its aboveground counterpart (De Deyn and Van der Putten, 2005); furthermore, on both land types, soils store massive amounts of organic carbon, the total amount of which (ca. $2500 \mathrm{Gt}$; Batjes, 1996; Hiederer and Köchyl, 2012) is much larger than the amount of carbon present in the atmosphere (ca. $800 \mathrm{Gt}$ ). Importantly, organic carbon storage per unit area is generally much higher on non-agricultural land (Poeplau et al., 2011; Hiederer and Köchyl, 2012). By allowing plants to grow, soils significantly contribute to the terrestrial carbon sink, which removes an amount equal to $30-40 \%$ of the carbon annually emitted by humans from the atmosphere (Le Quere et al., 2009). Soils, both those on agricultural and those on non-agricultural lands, are therefore a vital part of humanity's global life support system, just like the atmosphere and the oceans. An Earth without soils would 
Table 1. Conditions and trends with respect to soil erosion as assessed by experts (data from FAO and ITPS, 2015).

\begin{tabular}{lll}
\hline Region & Condition & Trend \\
\hline Asia & Poor & Negative \\
Latin America & Poor & Negative \\
Middle East and North Africa & Very poor & Negative \\
Sub-Saharan Africa & Poor & Negative \\
Europe and Eurasia & Fair & Positive \\
North America & Fair & Positive \\
Southwest Pacific & Fair & Positive \\
\hline
\end{tabular}

be fundamentally different from the Earth as we know it and would, in all likelihood, not be able to support human life as we know it.

No further arguments should be necessary to protect soils from the different threats posed to them by modern agriculture and other human activities. Yet, as is the case with many other natural resources, soils are under intensive pressure. Organic carbon loss, salinisation, compaction and sealing all threaten the functioning of soils to different extents in different areas of the world. One of the most important and perhaps the ultimate threat posed to soils is accelerated erosion due to agricultural disturbance. When soils are used for farming their natural vegetation cover is removed and they are often disturbed by tillage. The result is that, under conventional tillage, erosion rates by water on arable land are, on average, up to 2 orders of magnitude higher than those observed under natural vegetation. This acceleration creates a major imbalance as soil production is outstripped by soil erosion by a factor 10-100 so that soil is effectively mined (Johnson, 1987; Montgomery, 2007; Vanacker et al., 2007b). Eroded soil is, in many cases, truly lost and cannot be restored (although there are exceptions to this rule), which explains why land prices in areas heavily affected by erosion may remain lower than expected, even when excessive erosion has been halted for several decades (Hornbeck, 2012).

It is rather surprising that agricultural soil erosion is still such an important problem. Pre-industrial societies such as the Inca already understood that erosion threatened agricultural productivity and used soil conservation techniques such as terracing for centuries (Krajick, 1998). In France, environmental degradation by excessive water erosion of mountain hillslopes literally ruined the livelihood of entire mountain communities at the end of the 19th century (Robb, 2008). A similar situation developed in Iceland, where excessive wind and water erosion forced entire villages to be abandoned in the same period. In both countries overexploitation of the natural environment by subsistence farmers through excessive deforestation and overgrazing were key factors. Both countries responded to this situation: in Iceland the first soil conservation service of the world was founded in 1907 (Arnalds, 2005), while France started an extensive pro- gramme to restore its mountain environments (RTM) as early as 1860 (Lilin, 1986). In the United States, the Dust Bowl years (1930s) moved the erosion problem high up the political agenda: President Franklin Roosevelt not only erected the Soil Conservation Service but also, famously, said "A nation that destroys its soils destroys itself" (FAO and ITPS, 2015).

One might therefore expect that, by now, detailed information would exist on the status of the global soil resource and the necessary measures would have been taken to stop soil degradation due to human action and/or mitigate the consequences. Yet, this is clearly not the case: recent estimates of human-induced agricultural erosion amount to 25 40 for water erosion, ca. $5 \mathrm{Gt} \mathrm{yr}^{-1}$ for tillage erosion and 2 $3 \mathrm{Gt} \mathrm{yr}^{-1}$ for wind erosion (Van Oost et al., 2007; Govers et al., 2014). Measured soil production rates are, on average, ca. $0.036 \pm 0.04 \mathrm{~mm} \mathrm{yr}^{-1}$ (Montgomery, 2007) and are even lower on most agricultural soils because agricultural soils have a certain thickness and soil production rates decrease with increasing soil depth (Stockmann et al., 2014). Thus, over all agricultural land (arable and pasture) total soil formation would amount to maximum ca. $2 \mathrm{Gt} \mathrm{yr}^{-1}$, which implies that the global soil reservoir is depleted by erosion at a rate which is ca. 20 times higher than the supply rate. Although these numbers are only an approximation (for instance, they do not account for the fact that eroded soil may be re-deposited on agricultural land) they clearly illustrate that we are still far away from a sustainable situation: the rate at which the soil resource is being depleted is, over the longer term, a clear threat to agricultural productivity (FAO and ITPS, 2015). The loss of mineral soil is not the only issue: soil erosion also mobilises $23-42 \mathrm{Tg} \mathrm{yr}^{-1}$ of nitrogen and 14-26 $\mathrm{Tg} \mathrm{yr}^{-1}$ of phosphorus (Quinton et al., 2010). These numbers may be compared with the annual application rate of mineral fertilisers, which are ca. $122 \mathrm{Tg} \mathrm{yr}^{-1}$ for $\mathrm{N}$ and ca. $18 \mathrm{Tg} \mathrm{yr}^{-1}$ of mineral $\mathrm{P}$ respectively. At $2013 \mathrm{USA}$ mineral fertiliser prices of ca. USD $1.35(\mathrm{~kg} \mathrm{~N})^{-1}$ and ca. USD $4.75\left(\mathrm{~kg} \mathrm{P}^{-1}\right.$ (http://www.ers.usda.gov/data-products/ fertilizer-use-and-price.aspx) the annual amount of fertilisers mobilised by soil erosion is equivalent to ca. USD 35 billion for $\mathrm{N}$ and ca. USD 80 billion for P: this is a significant financial loss, even if one considers that the total global agricultural food production is currently valued at ca. USD 4000 billion (http://faostat.fao.org/site/613/DesktopDefault.aspx? PageID=613\#ancor). Most of these soil and nutrient losses take place in the hilly and mountain areas in the so-called Global South: a recent scientific appraisal by FAO and the ITPS (the Intergovernmental Technical Panel on Soils) showed that erosion problems are still increasing in Africa, Latin America and Asia (FAO and ITPS, 2015). The situation is perceived to be improving in Europe and North America (FAO and ITPS, 2015), even though soil losses in these regions are also often still above the tolerable level (Verheijen et al., 2009). Thus, it is especially the agriculture in the Global South (Latin America, Africa, the developing nations of Asia and the Middle East), where it is often one of 


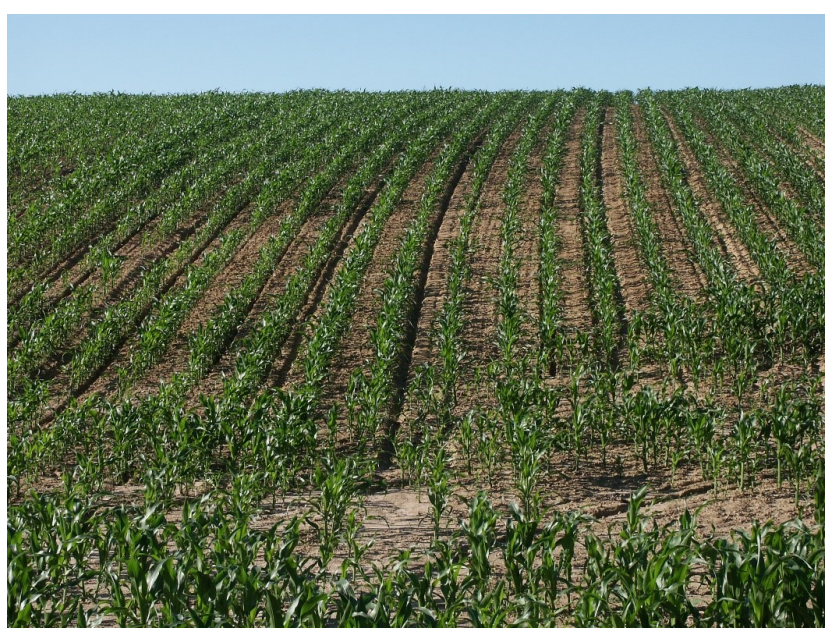

Figure 1. The presence of a dense network of rills and of significant deposition at the footslope (here in Huldenberg, Belgium, in July 2006) is as such sufficient proof for excessive soil erosion (in this case erosion exceeded $100 \mathrm{tha}^{-1}$ in a single event).

the main economic activities, which suffers excessively from these losses.

In this paper we reflect on why, despite these clear facts, effective soil conservation is not yet a done deal and what might be done about this. We argue that there is a need for a novel vision on soil conservation in the Global South, shifting the focus away from not only the technical issues of soil conservation but also soil conservation as such. Soil conservation efforts need to be framed into a general vision on how agriculture will develop in the Global South: this vision needs to account for soil protection, but must also guarantee food security and allow the development of an agricultural system that does provide a sufficient income to farmers. We will first assess possible reasons as to why soils do not yet get the protection they deserve. Thereafter, we will discuss the building blocks of a vision on future soil conservation.

\section{The status of soil conservation}

\subsection{Do we have the necessary data to guide soil conservation?}

Investing in the application of soil conservation measures is only meaningful when erosion rates are higher than acceptable. This can most easily be established when erosion rates can reliably be quantified. Quantitative information is indeed available for North America and Europe (Cerdan et al., 2010; NRCS, 2010). However, the quality of our estimates of soil erosion rates by water for other areas on the globe is often poor. Sometimes, estimates are based on a limited number of data which are simply extrapolated to larger areas: this often leads to bias, simply because erosion rates are generally measured at locations where erosion intensity is much higher than average (Boardman, 1998; Cerdan et al., 2010).
Also, when models are used to make an extrapolation, estimates are often incorrect. There are two reasons for this: (i) the models that are used are often improperly calibrated, i.e. model parameters are set to values that are not appropriate for the location under consideration, and (ii) the model parameterisation may be correct but the spatial data used to drive the model are inappropriate. A typical example of the latter is when slope lengths are directly derived from a digital elevation model so that the impact of slope breaks such as field borders is not accounted for (e.g. Yang et al., 2003). This can lead to a considerable overestimation of erosion rates (Desmet and Govers, 1996; Cerdan et al., 2010; Quinton et al., 2010). Erroneous predictions do not only make it difficult to identify the most vulnerable areas in which conservation measures are most urgent: they may also invalidate the costbenefit evaluations of soil conservation programmes and lead to disinformation of the general public about the extent and severity of the problem.

Although there is a clear need for better, quantitative data on erosion rates, the lack of such data is not the most important explanation as to why excessive soil erosion often still goes unchecked. While it may indeed be difficult to quantify erosion rates correctly, it is much easier to identify those areas where intense soil erosion is indeed a problem and where action is necessary, whatever the exact erosion rates are. This is, after all, what institutions such as the soil conservation services of Iceland and the United States did long before accurate erosion measurements were available. Simple visual observations on the presence of rills and gullies or wind deflation areas are clear indications that the implementation of conservation measures is necessary (Fig. 1). Another reason why an exact quantification is not always necessary is that conservation measures generally are not proportional: their implementation is most often of a yes/no type - one can decide whether or not to implement conservation tillage, but not by how much.

\subsection{Do we have the necessary technology for soil conservation?}

There is no doubt that soil conservation technology has matured over the last decades: we now have the tools to effectively reduce erosion rates to acceptable levels in many, if not all, agricultural systems. Conservation tillage is the tool of choice in many areas, especially in the Americas. This is hardly surprising: erosion plot research has consistently shown that water erosion rates under conservation tillage are reduced by 1 to 2 orders of magnitude in comparison to conventional systems (Montgomery, 2007; Leys et al., 2010). Moreover, the effectiveness of conservation tillage as calculated by plot studies is likely to be underestimated: for various reasons the effectiveness of conservation does increase if the slope length increases (Leys et al., 2010). As a consequence, water erosion rates under conservation tillage on moderate slopes are generally very low $\left(<1 \mathrm{tha}^{-1} \mathrm{yr}^{-1}\right)$ and 
often comparable to those occurring under natural vegetation (Montgomery, 2007). Conservation tillage may also be used to drastically control wind erosion not only because residue cover does reduce the shear stress to which soil particles are exposed but also because the presence of residue helps to keep the surface soil layer moist, thereby increasing its shear strength.

Conservation tillage is not always the best tool. It may be difficult or impossible to apply with certain crops, such as potatoes grown on ridges, and/or difficult to introduce into specific agricultural systems as it may affect the overall workload or the gender balance of the workload (Giller et al., 2009). It may also not be sufficient to implement conservation tillage as processes such as gully erosion may not be effectively controlled and may in some cases even be enhanced by conservation tillage as the latter is much more effective in reducing erosion than in reducing surface runoff (Leys et al., 2010). However, in such cases technological solutions also exist: they can consist of infrastructural measures such as stone bunds and terrace building in combination or vegetation measures such as grassed waterways, but proper land use allocation can also make a significant difference. Water and wind erosion rates can often be reduced to acceptable levels through the use of such measures in combination with modifications of tillage techniques and crop rotations (Sterk, 2003; Valentin et al., 2008; Nyssen et al., 2009).

Not only arable land can be affected by excessive erosion. Grazing lands may suffer from a drastic reduction in vegetation cover due to overgrazing and compaction, again resulting in excessive water and/or wind erosion with rates up to 2 orders of magnitude higher than those observed under natural conditions (Vanacker et al., 2007b). Reduction of grazing pressure (at least in a first stage) and the introduction of controlled grazing are key strategies (i) to restore the vegetation cover and (ii) to allow these lands to become productive again so that they can be sustainably used (Mekuria et al., 2007). Such measures can be further supported by the planting of trees (Sendzimir et al., 2011). Reforestation may also be a solution as it reduces erosion rates to near-natural levels but it has evident implications for the type of agriculture that can be supported (Vanacker et al., 2007b). Thus, as is the case on arable land, the key to erosion reduction on grasslands is in most cases the maintenance or restoration of a good vegetation cover, possibly supported by technical measures.

Erosion in agricultural areas is often directly related to not only agricultural activities but also the infrastructure related to these activities such as roads and field boundaries. Unpaved roads on sloping surfaces are important sources of sediment not only in many agricultural areas (Rijsdijk et al., 2007; Vanacker et al., 2007a) but also in cities (Imwangana et al., 2015). Water is often concentrated at field boundaries, thereby leading to gully formation (Poesen et al., 2003). Again, the necessary technological know-how to control such erosion phenomena is available: check dams, better water drainage infrastructure, the implementation of field buffer zones and a better landscape organisation all help to reduce sediment production on road networks and in built-up areas.

\subsection{Why, then, is soil conservation not more generally adopted?}

Thus, neither the lack of conservation technology nor the lack of data on the erosion hazard can fully explain why efficient soil conservation measures are still not implemented on most agricultural land, especially in the Global South. It has indeed long been clear that several factors other than (the lack of) scientific knowledge or data hamper the adoption of conservation tillage. These factors include the training level of the farmer, the farm size and work organisation as well as access to information. However, a thorough analysis by Knowler and Bradshaw (2007) showed that the effect of these variables was often ambiguous (when different studies are compared) and that few, if any, variables showed a consistent effect. One might conclude from this that changing farming practices must be inherently difficult, as our understanding of controlling factors is relatively poor and many barriers to the adoption of novel technology need to be overcome. This is not only a problem in the Global South: in Europe the adoption of conservation tillage is also slow in many countries due to a multitude of factors, including the fact that soil tillage is deeply rooted in the culture of many farmers (Lahmar, 2010).

Clearly, farming systems are, to some extent, "locked in": they rely on well-tried technology, division of labour and crop types and are therefore difficult to change. There are, nevertheless, also cases where farming systems change rapidly and conservation technology is quickly adopted. Once the necessary technology was available, conservation tillage spread very rapidly through most of Argentina and Brazil: in Argentina, it took ca. 20 years (from 1990 to 2010) to bring ca. $80 \%$ of the arable land under no-till (Peiretti and Dumanski, 2014), thereby effectively halting excessive soil erosion on most of the arable land of the country. In Brazil, more than 25 million ha of land was under no-tillage in 2006, whereas the technique was virtually unused before 1990 (Derpsch et al., 2010). Rapid changes in agricultural systems are not limited to the adoption of conservation tillage. When subsistence farmers in remote areas gain access to profitable markets, very rapid transformations can occur, even in areas where existing technology is poor: such changes can have very negative effects in terms of soil degradation rates as a switch to cash cropping may introduce crops with which a much higher erosion risk is associated (Valentin et al., 2008). Thus, while cultural and technological barriers to change certainly do exist, farmers are most certainly capable of rapid change. Whether such rapid change occurs critically depends on whether farmers think change will bring them a personal gain.

This is where the problem lies. Under some conditions, the adoption of conservation technology is indeed clearly eco- 
nomically beneficial to the farmer: this appears to be true for large farming operations in (sub)tropical regions growing cash crops such as soy beans (Peiretti and Dumanski, 2014). But in most other cases the direct benefits of the implementation of conservation agriculture and/or other soil conservation measures are small, if they exist at all. This appears to be the case for both large-scale mechanised agriculture in the temperate zone as well as for subsistence hillslope farming in developing countries (Knowler et al., 2001). In both scenarios, potential savings are offset by additional costs: in mechanised systems the cost of machinery and agrochemicals offsets savings in fuel costs (Zentner et al., 1996; Janosky et al., 2002), while in traditional hillslope farming extra work hours are needed to maintain conservation structures and some land has to be sacrificed to implement these structures, thereby reducing overall yields (Nyssen et al., 2007; Quang et al., 2014). Importantly and contrary to common belief, crop yields do not rise significantly in conservation systems if no additional inputs are provided: this is true for advanced technological systems (Van den Putte et al., 2010; Pittelkow et al., 2015) as well as for tropical smallholder farming (Brouder and Gomez-Macpherson, 2014). As a consequence, farmers often do not have direct incentives to implement soil conservation measures and change becomes difficult to put into effect.

One may argue that benefits should be considered not only at the level of the individual farmer but also at the societal level, where soil conservation may generate cobenefits. Often, carbon storage and biodiversity protection under conservation systems are mentioned as important ecosystem services for which farmers could be paid. Research in the last decade has consistently shown that carbon storage gains in conservation systems are lower than was anticipated two decades ago and are generally well below $1 \mathrm{t} \mathrm{Cha}^{-1} \mathrm{yr}^{-1}$ (Oorts et al., 2007; Angers and EriksenHamel, 2008; Christopher et al., 2009; Eagle et al., 2012; Govers et al., 2013). Furthermore, paying farmers to store carbon would only be viable at much higher carbon prices than the current market prices, which are around USD 10 $15 \mathrm{t}^{-1}$ (Grace et al., 2012; Govers et al., 2013). Paying farmers at current market prices can only generate a relatively small economic benefit for the farmer and prices would have to rise significantly for soil carbon storage to become an important element on the farmers' balance sheet. On the other hand, soil conservation generally has a positive impact on (soil) biodiversity on the farm land as soils are less frequently disturbed (Mader et al., 2002; Verbruggen et al., 2010). Where agriculture is interspersed with densely populated areas, additional co-benefits may consist of a reduction of flooding and/or siltation of sewage systems and water treatment plants, which are important problems in many areas in Europe (Boardman et al., 1994). These benefits, however, are difficult to convert to financial income for the farmer. This is not only because the economic value of increased biodiversity on farmland is difficult to quantify but also because such on-farm benefits in biodiversity have to be weighed against possible off-farm losses (see below). The reduction in flooding risk, on the other hand, will generally not be considered as a benefit by society but rather as damage repair: the problems were caused by agriculture in the first place.

\section{The way forward}

How, then, should we proceed to stimulate a more rapid adoption of soil conservation measures to protect the world's soil resource? The answer to this question will obviously depend on the characteristics of the local agro-ecological system. Agricultural systems show a large variety so that not only the factors impeding the adoption of conservation tillage vary locally (Knowler and Bradshaw, 2007) but also the tools that societies have at their disposal to reduce it.

Western societies with highly developed information systems tackle the problem by means of a policy combining regulation (e.g. by forbidding the cultivation of certain crops on land that is very erosion-prone) and subsidies or compensations in combination with well-guided campaigns to inform farmers on the potential benefits and risks for themselves as well as for the broader society. Such combined approaches have had demonstrable success in various parts of Europe and North America, where farmers are not only well trained and highly specialised but also dependent to a large extent on subsidies, giving the administrations the necessary financial leverage to stimulate or even coerce farmers (Napier et al., 1990). As a result erosion rates in North America have gone down considerably over the last decades and are still declining (Kok et al., 2009). One may therefore assume that in these societies erosion rates can be reduced to tolerable levels provided that the necessary policies are maintained and/or strengthened. Countries with a strong central government that can impose decisions on land use and soil conservation, as is the case in China, can successfully reduce erosion: the excessive erosion rates on the Chinese Loess Plateau were strongly reduced through massive government programmes implementing erosion control measures (Chen et al., 2007; Zhao et al., 2016)

These approaches are, at present, not possible in most countries of the Global South. Many governments in the Global South are not able to implement a successful soil conservation policy as they do not have at their disposal the necessary data and/or the necessary political and societal instruments to do so. At first sight it may therefore appear unlikely that soils will become effectively protected in most of the developing world within a foreseeable time span. Yet this conclusion foregoes the fact that agriculture in the Global South, and especially in sub-Saharan Africa, will see fundamental changes in the next decades. At least three fundamental tendencies can be identified that will change the nature of agriculture in the Global South in the 21st century: these should 
be accounted for when developing a vision on soil conservation.

In many areas where soils are most seriously threatened, the human population will continue to grow strongly. In the next decades, the locus of world population growth will shift in an unprecedented manner. Population growth in the Global North has stopped and many regions in the Global South will follow suit in the next decades: Asia is expected to reach its maximum population around 2050. China's population will peak around 2030 and that of India no later than 2070. Latin America will follow around 2060 (http: //esa.un.org/unpd/wpp/, Lutz and KC, 2010; Gerland et al., 2014). Sub-Saharan Africa is a different matter: here the demographic transition started only after the Second World War and the population will continue to grow rapidly during most of the 21 st century. As a result of these diverging tendencies the distribution of the world's population will have changed beyond recognition in 2100: Europe's share in the global population will have fallen from its maximum of ca. $22 \%$ in 1950 down to ca. $6 \%$ in 2100 , while the share of Africa will rise from ca. $9 \%$ in 1950 to ca. $39 \%$ in 2100 (http://esa.un.org/unpd/wpp/).

The population in the Global South will also become more urban. By $2050 \mathrm{ca}$. two-thirds of the global population is expected to live in cities (as compared to ca. $55 \%$ at this moment). Urbanisation rates are especially high in Africa, where the fraction of urban population is expected to increase from 40 in 2014 to $55 \%$ in 2050, and in Asia, where urbanisation will increase from ca. 47.5 to ca. $65 \%$ over the same period (United Nations, 2014). There is no alternative for this evolution: despite all their problems, cities are the engines of modern economic development as they allow a population to create the added value that is so desperately needed through advantages of scale, intense interaction and exchange (Glaeser, 2011). This is the fundamental reason of the attractiveness of cities and the major factor explaining rural to urban migration: poor rural populations perceive the city as a place of opportunity and moving there as an opportunity to improve their own lives or at least those of their children (Perlman, 2006; Saunders, 2011). A consequence of this massive migration movement is that rural populations rapidly age and that the average farm worker is significantly older than the average non-farm worker (40 vs. 34 years in Africa, http://www.gallup.com/poll/168593/ one-five-african-adults-work-farms.aspx). Clearly, the evolution sketched above is a generalisation: local dynamics depend, amongst other things, on the presence of attractive labour opportunities in the cities and the local availability of land (Ellis-Jones and Sims, 1995).

It is not overly optimistic to expect that, while population growth continues, these populations will at the same time gain in purchase power. While incomes in southern Asia and especially sub-Saharan Africa are presently much smaller than those in the Global North, their growth rates are, fortunately, much bigger. For example, Ethiopia's economy has, over the last decade, consistently been growing at 8 to $10 \%$ per year, leading to a rise of the per capita gross national income from USD 110 (2015 dollars) in 2004 to USD 550 in 2015 (http://data.worldbank.org/country/ethiopia).

Combined, these tendencies will lead to an increased market demand for food. Furthermore, diets will move away from a diet largely based on cereals towards a more varied (but not necessarily healthier) food palate in which meat is likely to have a larger share than is currently the case. Global estimates therefore sometimes predict that global food production (in terms of kcal) will more or less double in the first half of the 21st century (Tilman et al., 2011), but an increase in demand by $60-70 \%$ is more likely (Alexandratos and Bruinsma, 2012). As (relatively) more people will live in cities, there will be relatively fewer people working on the land to produce the food that is necessary. Furthermore, as most of future population growth will take place in subSaharan Africa, food demand will rise most rapidly in this area.

Thus, agriculture in the Global South will be fundamentally different from what it is now in less than a century. More food will have to be produced with less people and the increasingly urban population will more and more rely on markets to obtain the food it needs. This begs a basic question: how can we make sure that the soils necessary to produce all this food are sustainably managed and preserved for future generations?

\section{Soil conservation in a changing global context}

Two contrasting pathways can be followed to meet the expected increase in food demand in the Global South. More food can be produced either by extending the area over which current food production systems are applied or by agricultural intensification, i.e. by increasing the amount of food produced per unit of land.

Both pathways are, in principle, possible: until present, Africa has followed the first path. Over the last five decades, the increasing food demand of African populations has mainly been met by increasing the area used for farming, while yields per unit of surface area remained stable and very low (Henao and Baanante, 2006). This evolution sharply contrasts with the one observed in most parts of Asia: here agricultural production was mainly increased through intensification (Henao and Baanante, 2006). In Asia, the Green Revolution led to a dramatic rise in agricultural yields through the combination of new crop varieties, better farming technology and the increased use of fertilisers. As a consequence, Asia now manages to feed its population much better than it did in 1970: the amount of available kcal per person rose from ca. 2000 to ca. $2400 \mathrm{kcal}$ (South Asia) or even $3000 \mathrm{kcal}$ (East Asia) in 2005 (Alexandratos and Bruinsma, 2012) despite the fact that the amount of land used for agriculture only marginally increased (Henao and Baanante, 
2006) and despite the fact that the population in these regions increased from 0.98 to 1.53 billion (East Asia) and from 1.06 to 2.20 billion (South Asia) over the same period (http://esa.un.org/unpd/wpp/).

While the challenge for African agriculture is not dissimilar to that of Asia in the 1960s, Africa does not necessarily have to go down the same route. In principle, it could continue to follow the areal extension strategy policy for some time to come. At present, ca. 290 million ha of agricultural land is in use in Africa, but another 400 million ha of African land is suitable (good) or very suitable (prime) for agriculture (Alexandratos and Bruinsma, 2012). Therefore, there is scope for a strategy whereby significantly more land would be used for agriculture than is the case at present although this would pose important problems: a large fraction of the suitable land is located in politically unstable countries and/or far from existing markets (Chamberlin et al., 2014).

An extension strategy may, at first sight, be attractive from the point of view of soil conservation. One might indeed argue that this would be based on agricultural technology that has been in use for decades, and may therefore be best suited to increase agricultural production without causing excessive soil degradation. Indeed, the occurrence of erosion in mechanised, intensive agricultural systems is often attributed to the loss of traditional soil conservation methods (Bocco, 1991). Averting intensification and aiming at area extension may therefore seem a suitable solution to avoid excessive soil degradation as traditional farming methods can be maintained and optimised to be as environmentally friendly as possible. Many organisations do indeed stress environmental protection and sustainability as key issues to be addressed in the further development of African agriculture and explicitly state that Africa should indeed follow a path different from the Asian Green Revolution (De Schutter, 2011).

While it is evident that we should learn from agricultural developments in Asia and avoid the dramatic negative effects the Asian Green Revolution had in some places, we argue here that tropical smallholder farming does need intensification for soil conservation to become successful. This intensification should be smart: it is not sufficient that intensification is sustainable so that the capability of the natural resources to meet the needs of future generations is not jeopardised. Intensification strategies should also maximise the opportunities of current and future farmers to generate an acceptable income by providing them with access to profitable markets and supplying them with the necessary knowledge and technology to produce for these markets. Smart intensification requires an approach that does not focus on the conservation of natural resources alone but also on the creation of added value using a future-oriented perspective and the quantity and quality of food production and supply. Clearly, improving the livelihood of the farmers and farming communities should be a key element. However, the capability of this farming community to provide the necessary agricultural supplies to an ever growing non-farming population also needs to be taken into account. Thus, it is important to consider not only the current socio-economic conditions but also how demographic and socio-economic conditions are likely to change in the future. We argue that smart intensification will not only make soil conservation more achievable but that it would also allow for reaping additional environmental benefits that may be lost when a less intensive or less future-oriented development path is chosen. As is the case for "smart cities", we do not believe a single, all-encompassing definition of smart intensification can be formulated. However, we summarised the components that we consider to be essential in Fig. 2. In the rest of the paper we focus the discussion on how soil conservation may benefit from smart intensification.

Smart intensification will allow for the most erosionprone land to be spared from agriculture, thereby reducing landscape-scale erosion rates. When farmers select land for arable production, they will select the most suitable land that is available. In general this means that, for obvious reasons, flatter land is preferred over steeper land (Van Rompaey et al., 2001; Bakker et al., 2005). Steep lands are generally much more difficult to cultivate than flatter areas and yields can be expected to be lower in comparison to yields (for the same amount of inputs) on flat land because soils are intrinsically less productive and/or because soil productivity is negatively affected by accelerated erosion (Stone et al., 1985; Ellis-Jones and Sims, 1995; Lu and van Ittersum, 2004). The combination of both effects (more labour required and lower yields) invariably implies that the net returns of arable farming decrease with increasing terrain steepness. The total amount of erosion as well as the amount of erosion per unit of crop yield will therefore necessarily increase when area expansion is preferred over intensification (Figs. 3, 5).

Increasing agricultural production in Africa through areal extension alone would therefore imply that overall soil losses would increase much more rapidly than agricultural production would. If, on the other hand, agricultural yields on good agricultural land would be improved, it may be possible to set aside some of the marginal land that is currently used for arable farming. The somewhat counterintuitive result of this will be that, even if erosion rates on the arable land that remains in production were to increase due to intensification, the overall soil loss (at the landscape scale) would still decrease (Fig. 3).

Smart intensification will conserve soil carbon, which will, in turn, reduce erosion risks. Over the last decades, a significant body of scientific literature has emerged on the potential of agricultural land to store additional soil organic carbon through the use of appropriate management techniques. While studies do suggest that some gains are indeed possible, most studies report modest gains at best. Reported average sequestration rates under conservation tillage in Canada are between 0 and $0.14 \mathrm{tC} \mathrm{ha}^{-1} \mathrm{yr}^{-1}$ in Canada (VandenBygaart et al., 2010), while an average sequestration rate of $0.12 \mathrm{tC} \mathrm{ha}^{-1} \mathrm{yr}^{-1}$ has been calculated for the USA (Eagle 


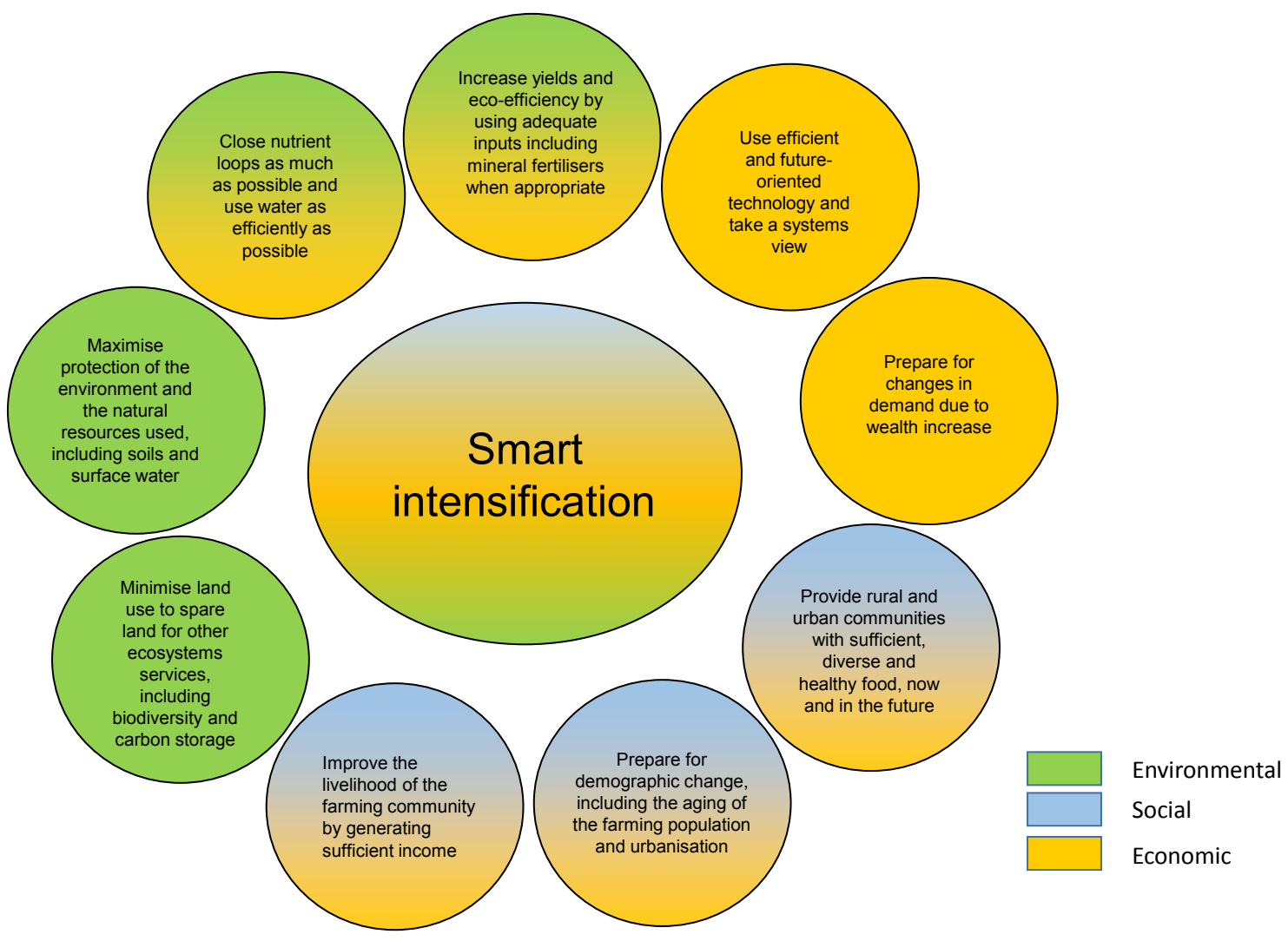

Figure 2. Different aspects of smart agricultural intensification. Colouring refers to main reason as to why each aspect is important.

et al., 2012). In a study covering 12 study sites in three Midwestern states of the USA, Christopher et al. (2009) did not find any significant increase in soil organic carbon storage under no-till in real farming conditions. Experimental studies also showed that under agroforestry gains in soil organic carbon are small, with an average of $0.25 \mathrm{tC} \mathrm{ha}^{-1} \mathrm{yr}^{-1}$ (Govers et al., 2013). These findings contrast not only with claims in the literature (Ramachandran Nair et al., 2009) but also with the observation that soil carbon stocks on natural (or undisturbed) land are generally much higher (often more than three times higher) than those observed on arable land (e.g. Poeplau et al., 2011; Hiederer and Köchyl, 2012).

The latter is related to two main factors: (i) biomass is not removed from natural land, which results in larger organic carbon inputs, and (ii) these lands are not mechanically disturbed which reduces carbon respiration rates. Thus, more soil carbon will be conserved when the extent of agricultural land is reduced and more land is preserved under or restored towards natural conditions. An additional beneficial effect of the latter is that soil organic carbon stocks may increase on agricultural land with increasing agricultural yields, provided that the residual biomass is adequately managed (VandenBygaart et al., 2010; Minasny et al., 2012): this, in turn, will reduce the erosion and degradation risk (Torri and Poesen, 1997). Thus, intensification will allow for more carbon to be preserved than areal extension (Figs. 3, 5). The fact that intensification is beneficial for soil carbon conservation has also been demonstrated at the global level: agricultural intensification has allowed for avoidance of ca. $161 \mathrm{Gt}$ of carbon emissions from the soil to the atmosphere between 1960 and 2005 (Burney et al., 2010).

Smart intensification will help to make agriculture in the Global South more water-efficient. Agriculture is by far the largest global consumptive user of blue water (water extracted from rivers and groundwater): at the global scale, over $80 \%$ of all consumptive water use is related to agricultural activities (e.g. Döll et al., 2009). As the amount of available water will not significantly increase in the future, a more efficient water use is a prerequisite to increase agricultural production in the Global South. Less productive systems are often more water-intensive, i.e. more units of water are needed for each unit of crop that is produced. Striving towards higher yields will remedy this problem as it allows for the amount of crop produced per unit of water to increase (Rockström et al., 2007). Higher yields are therefore a means to increase water conservation and to make sure that more water is available for the functioning of non-agricultural ecosystems. Clearly, the realisation of this potential requires other measures as well such as a realistic pricing of water and water use monitoring in areas where water scarcity is a problem so that in- 


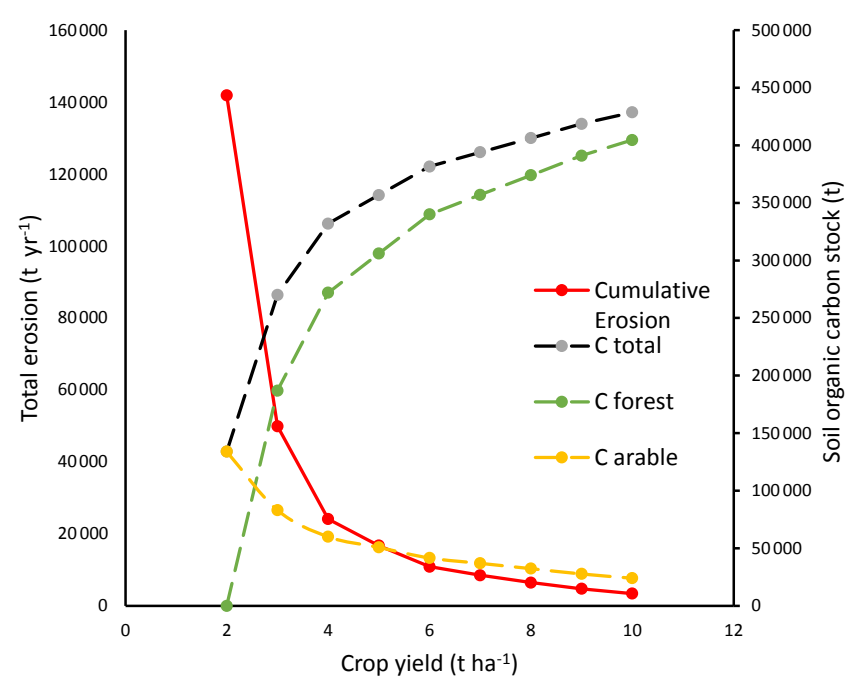

Figure 3. Modelled total erosion ( $\mathrm{t} \mathrm{yr}^{-1}$ left axis) and soil organic carbon stocks ( $t$, right axis) vs. crop yield per hectare for a hypothetical test area of 2900 ha and assuming a total cereal production of $5000 \mathrm{t}$. We assumed that slope gradients $(\sin \theta)$ were uniformly distributed between 0.02 and 0.58 , i.e. an area of 100 ha in each 0.02 slope class. The crop yield shown is the crop yield on a zero slope and relative crop yield $(P)$ is assumed to vary with slope: $P=1-(\sin \theta)^{0.5}$. Erosion $\left(E, \mathrm{tha}^{-1} \mathrm{yr}^{-1}\right)$ is assumed to vary with slope gradient according to the slope function derived by Nearing (1997): $E \sim-1.5+17 /[1+\exp (2.3-6.1 \sin \theta)]$, and an erosion rate of $10 \mathrm{tha}^{-1} \mathrm{yr}^{-1}$ is assumed on a 0.09 slope. Soil organic carbon stocks per unit area are assumed to be 40 on arable land and $170 \mathrm{tha}^{-1}$ under forest (Poeplau et al., 2011). The total soil organic carbon stock (C total) in the area strongly increases with increasing crop yield because the gain in soil organic carbon stocks on forested land ( $\mathrm{C}$ forest) is much more important than the loss on arable land ( $\mathrm{C}$ arable).

efficient use of this scarce resource can be prevented. Again, the implementation of such systems will be far more efficient in high-yield systems as the return per unit of capital cost will be higher.

Smart intensification is beneficial for biodiversity at the landscape scale. Environments where intensive agriculture is dominant are often very poor in terms of biodiversity. One might therefore suggest that, in order to preserve biodiversity, intensification should be avoided and a certain biodiversity on agricultural lands maintained. Again, such a strategy would necessarily imply that more land would be needed to produce the same amount of agricultural goods. Recent studies have consistently shown that such a strategy is not beneficial for biodiversity at a larger scale: the biodiversity gained on agricultural land is, in general, not sufficient to compensate for the additional biodiversity loss due to agricultural land expansion (e.g. Phalan et al., 2011b; De Beenhouwer et al., 2013; Schneider et al., 2014). Thus, land sparing and concentrating intensive agriculture on designated areas is generally a better strategy than land sharing with low-intensity

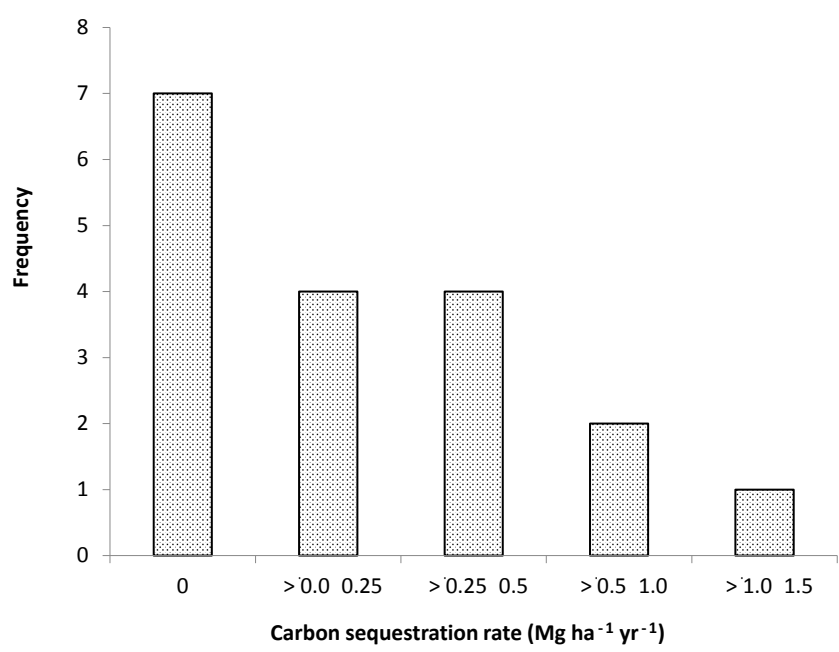

Figure 4. Frequency distribution of experimentally observed carbon sequestration rates under agroforestry. Data from 18 paired field studies in both (sub)tropical and temperate climates (details and references of studies in Govers et al., 2013). The average soil organic carbon sequestration rate reported over all 18 studies is $0.25 \pm 0.33 \mathrm{tha}^{-1} \mathrm{yr}^{-1}$.

agriculture that will occupy a much larger fraction of the available land (Fig. 5). Sparing will not always be the best strategy as this will depend on local conditions: for instance, wildlife-friendly agriculture may be the best solution in the buffer zones around wildlife reserves.

Smart intensification will increase the added value of the land used for agricultural production and hence make the implementation of conservation measures economically sound. Clearly the economic value of a good such as arable land depends on the economic return that can be gained from the use of it. Intensification will allow for these returns to increase. This is especially true for sub-Saharan Africa, where yields are still extremely low (Neumann et al., 2010). While there are many reasons for this, a key factor is that African soils are chronically underfertilised (Henao and Baanante, 2006; Keating et al., 2010). The amount of fertiliser used per unit of surface are of agricultural land in Africa is only $10 \%$ of what is being used in Europe or the United States: the consequence is that, in many cases, the nutrient balance of many African agricultural systems is negative, i.e. more nutrients are removed through harvesting than there are supplied by fertilisation (Smaling et al., 1993; Henao and Baanante, 2006). This negative balance is further aggravated by soil erosion, which annually mobilises more nutrients than are applied in sub-Saharan Africa (Quinton et al., 2010). Even a modest increase in fertiliser use may therefore allow for a significant boost to agricultural yields in sub-Saharan Africa, at least if this increase were accompanied by other measures such as the introduction of high-yield varieties and the necessary training for the farmers (Sanchez, 2010; Twomlow et al., 2010; Mueller et al., 2012). 


\section{Land use distribution}

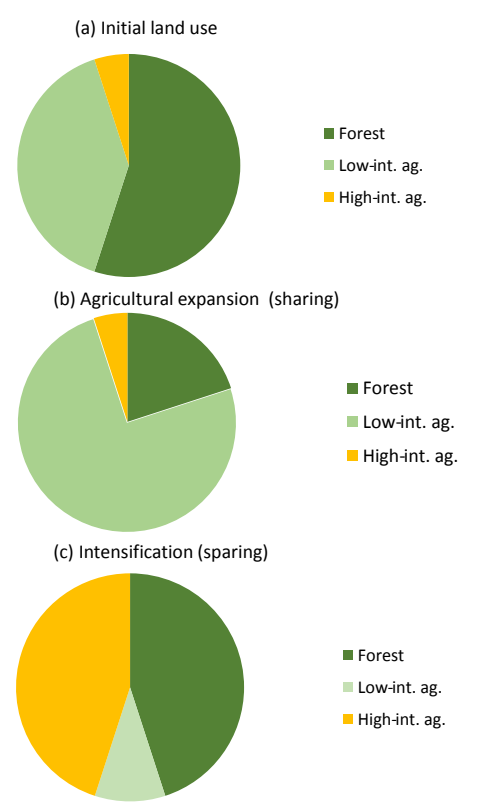

SOC stocks

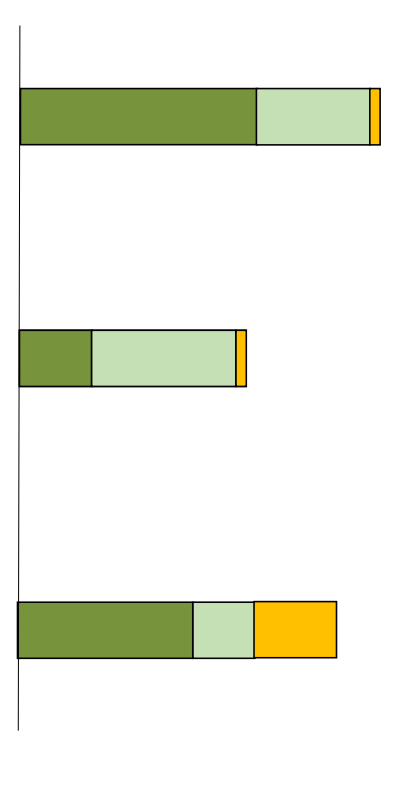

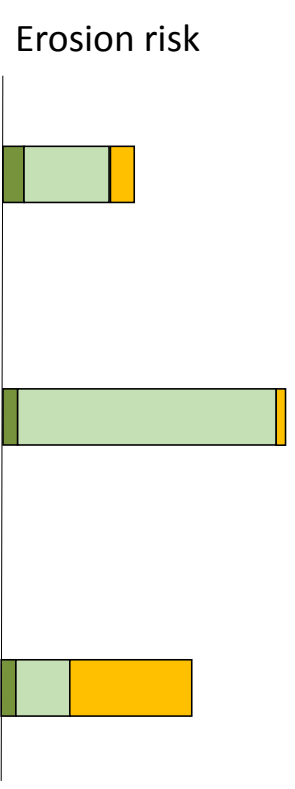

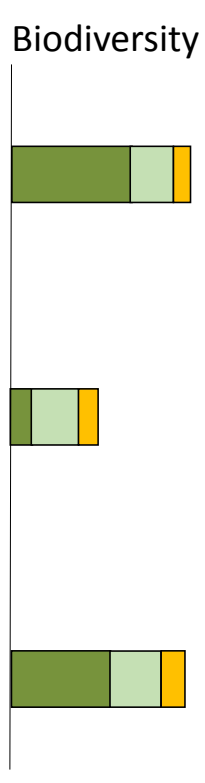

Figure 5. Semi-quantitative illustration of the effects of a significant increase in agricultural production through smart intensification (sparing land) vs. agricultural expansion (sharing land) on soil organic carbon stocks, the erosion risk and biodiversity. We assume that in a given area the required increase in agricultural production is such that, if yields are not increased, the entire area that is potentially suitable for agriculture ( $80 \%$ of the total area) has to be used for agriculture and that smart intensification would reduce the area needed to ca. $55 \%$ of the total area. The bar graphs give a semi-quantitative assessment, at the landscape scale, of the impact of these alternatives according to current scientific insights. Smart intensification is beneficial with respect to soil organic carbon storage because soil organic stocks under natural forest are much higher than under arable land (e.g. Poeplau et al., 2011). Smart intensification will reduce total soil erosion because less marginal (sloping) land needs to be taken into production (e.g. Van Rompaey et al., 2002). Finally, smart intensification is beneficial for biodiversity because more forest is preserved and the biodiversity of undisturbed forests is much higher than that of land used for agriculture (e.g. Phalan et al., 2011a).

Higher agricultural yields will increase the added value that may be produced per unit of agricultural land and hence its value. A consequence of this is that the economic stimulus to implement conservation measures on this land will increase as land will become a more precious resource. Furthermore, intensification will also reduce the overall conservation investment that has to be made as the acreage that needs to be treated will be smaller, which will allow for the available resources to be concentrated on a smaller area. Finally, many conservation strategies are based on the use of crop residue (i) to return nutrients and carbon to the soil and (ii) to reduce the soil erosion risk. Such strategies are likely to be more successful when more residue per unit of area is available. Case studies have repeatedly shown that the mechanisms described above can indeed lead to more effective soil conservation under increasing intensification and population pressure (e.g. Tiffen et al., 1994; Boyd and Slaymaker, 2000).

Smart intensification will help to create the market opportunities needed for sustainable agriculture. The dramatic increase in population that will occur in the Global South over the next century, in combination with rapid urbanisation and economic growth, make the transition towards a market- oriented agriculture inevitable. This is not a bad thing: all too often we have a far too rosy view on the potential of subsistence agriculture. The truth is that subsistence farming does not generate the necessary financial means for the farmers to get out of poverty, although improvements in agricultural technology may contribute to increased food security (Harris and Orr, 2014). Only when farmers have access to markets they can generate an income that allows them to fully participate in society so that they can not only benefit from the material perks of modern life but also provide a high-quality education to their children and the necessary health care to those who need it: soil conservation as such cannot achieve this (Posthumus and Stroosnijder, 2010). Case studies support that a symbiosis between the development of a marketoriented agriculture and soil conservation is indeed likely as market access provides farmers with the economic incentives to implement soil conservation measures (Boyd and Slaymaker, 2000). Again, the transition from a subsistence to a market-oriented system will almost inevitably have to be accompanied by intensification as the latter will allow a better return on both capital and input investment. 
Smart intensification will not be sufficient to achieve adequate soil conservation (but it will help). The points raised above illustrate that adequate soil conservation is much more likely to be achieved if more intensive agricultural systems are developed in the Global South as the economic and environmental stimuli to implement soil conservation measures will be much larger. Yet, the experiences in Europe and North America illustrate that this may not be sufficient to achieve adequate soil conservation and that government stimulation (through financial measures) and/or coercion may be necessary to further reduce soil degradation. It is, however, the magnitude of such efforts and their effectiveness that should be considered. The societal efforts and costs that will be needed to achieve adequate soil conservation will be far smaller when less land is used for agriculture as much less land will need treatment. Furthermore, one may also imagine that efforts to convince farmers to adopt conservation measures will be more successful in an intensive, marketoriented agricultural system as they will, generally, be more open to changes and both governments and other stakeholders will have more leverage in discussions on how the agricultural system needs to be organised. This is, obviously, no guarantee for success as potential direct financial benefits may seduce the stakeholders to neglect the necessary investments to achieve long-term sustainability. The latter is a problem that occurs everywhere where environmental and economic concerns conflict and, while general principles to resolve such problems have been formulated (Ostrom, 2009), specific policies to deal with this conflict will depend on local conditions.

\section{Conclusions}

All too often, soil conservation is discussed in isolation, whereby much attention is given to the effectiveness of technical solutions in reducing excessive soil and water losses at a given location. Agriculture, however, is a system wherein lateral connections at different scales are very important: actions at a specific location will necessarily have implications at other locations. Agricultural systems are also subject to constant change as they respond to changes in population numbers, population distribution, economic wealth and cultural preferences. A coherent vision on the development of soil conservation in 21st century needs to account for this context and needs to consider both the spatial and temporal dynamics of agricultural systems.

While it is certainly true that conservation technology can be further developed other considerations may be more important for the successful implementation of soil conservation programmes. In our view, smart intensification is an essential ingredient of any strategy seeking efficient soil conservation while at the same time meeting the growing food demands of a strongly increasing, more urbanised global population. Smart intensification will help to reduce the land surface area exposed to a high soil degradation risk, while it will, at the same time, increase the return on the soil conservation measures that will still be necessary. Smart intensification will also allow for additional environmental benefits to be reaped in terms of soil organic carbon storage, biodiversity and water availability. It will also be directly beneficial to the farmers, allowing them to produce food for more people and to achieve an acceptable income. It is therefore no surprise that, when considering these other angles, other researchers have reached similar conclusions, stating that agriculture in the Global South and particularly in Africa needs to intensify and that the exclusive focus on smallholders as engines for growth needs to change (Collier and Dercon, 2009).

Intensification is not a panacea that magically solves all problems. Striving towards higher crop yields will require the use of more external inputs, including the use of mineral fertilisers. This is often assumed to be detrimental to the environment: yet this only will be true if fertilisers are used excessively, as is the case now in many areas of the world (Sattari et al., 2012; Lassaletta et al., 2014; Zhang et al., 2015). If correctly used, the environmental benefits of judicious mineral fertiliser use will more often than not outweigh their potential negative impacts by reducing the amount of land needed for agricultural production (Tilman et al., 2011). Furthermore, intensification will require higher energy and capital inputs per unit of surface area: these extra investments will partly be compensated for by the fact that a smaller area of land needs to be cultivated, but access to markets will often be essential to make intensification profitable.

Smart intensification as such will not be sufficient to reduce soil loss to acceptable levels: in intensive systems, soil losses are also often higher than is tolerable and conflicts between (long-term) environmental and (short-term) economic goals will be present. Yet, these problems will be easier to tackle when we give smart intensification adequate consideration in any plan on future agricultural development in the Global South.

\section{Data availability}

All data used in this paper are in the public domain and can be accessed through the URL links provided.

Competing interests. The authors declare that they have no conflict of interest.

Acknowledgements. This paper greatly benefited from the critical comments of Martin Van Ittersum and an anonymous referee. The financial support of STAP (Scientific and Technical Advisory Panel of the Global Environmental Facility) and the IUAP project SOGLO (The Soil System under Global Change, IUAP P7/24) is gratefully acknowledged. 
Edited by: J. Wallinga

Reviewed by: M. van Ittersum and one anonymous referee

\section{References}

Alexandratos, N. and Bruinsma, J.: World agriculture towards 2030/2050: The 2012 revision, ESA Working paper, 2012.

Angers, D. A. and Eriksen-Hamel, N. S.: Full-inversion tillage and organic carbon distribution in soil profiles: A meta-analysis, Soil Sci. Soc. Am. J., 72, 1370-1374, doi:10.2136/sssaj2007.0342, 2008.

Arnalds, A.: Approaches to Landcare-a century of soil conservation in Iceland, Land Degrad. Dev., 16, 113-125, 2005.

Bakker, M. M., Govers, G., Kosmas, C., Vanacker, V., van Oost, K., and Rounsevell, M.: Soil erosion as a driver of land-use change, Agr. Ecosyst. Environ., 105, 467-481, doi:10.1016/j.agee.2004.07.009, 2005.

Batjes, N. H.: Total carbon and nitrogen in the soils of the world, Eur. J. Soil Sci., 47, 151-163, doi:10.1111/j.13652389.1996.tb01386.x, 1996.

Boardman, J.: An average soil erosion rate for Europe: Myth or reality?, J. Soil Water Conserv., 53, 46-50, 1998.

Boardman, J., Ligneau, L., de Roo, A., and Vandaele, K.: Flooding of property by runoff from agricultural land in northwestern Europe, Geomorphology, 10, 183-196, 1994.

Bocco, G.: Traditional knowledge for soil conservation in central Mexico, J. Soil Water Conserv., 46, 346-348, 1991.

Boyd, C. and Slaymaker, T.: Re-examining the "more people less erosion" hypothesis: Special case or wider trend, Natural Resource Perspective, 63, 1-6, 2000.

Brouder, S. M. and Gomez-Macpherson, H.: The impact of conservation agriculture on smallholder agricultural yields: A scoping review of the evidence, Agr. Ecosyst. Environ., 187, 11-32, 2014.

Burney, J. A., Davis, S. J., and Lobell, D. B.: Greenhouse gas mitigation by agricultural intensification, P. Natl. Acad. Sci. USA, 107, 12052-12057, doi:10.1073/pnas.0914216107, 2010.

Cerdan, O., Govers, G., Le Bissonnais, Y., Van Oost, K., Poesen, J., Saby, N., Gobin, A., Vacca, A., Quinton, J., Auerswald, K., Klik, A., Kwaad, F., Raclot, D., Ionita, I., Rejman, J., Rousseva, S., Muxart, T., Roxo, M. J., and Dostal, T.: Rates and spatial variations of soil erosion in Europe: A study based on erosion plot data, Geomorphology, 122, 167-177, doi:10.1016/j.geomorph.2010.06.011, 2010.

Chamberlin, J., Jayne, T. S., and Headey, D.: Scarcity amidst abundance? Reassessing the potential for cropland expansion in Africa, Food Policy, 48, 51-65, doi:10.1016/j.foodpol.2014.05.002, 2014.

Chen, L., Wei, W., Fu, B., and Lü, Y.: Soil and water conservation on the Loess Plateau in China: review and perspective, Prog. Phys. Geogr., 31, 389-403, doi:10.1177/0309133307081290, 2007.

Christopher, S. F., Lal, R., and Mishra, U.: Regional study of no-till effects on carbon sequestration in the midwestern United States, Soil Sci. Soc. Am. J., 73, 207-216, doi:10.2136/sssaj2007.0336, 2009.

Collier, P. and Dercon, S.: African agriculture in 50 years: Smallholders in a rapidly changing world?, FAO Expert meeting on how to feed the world in 2050 (June 2009), FAO, 13 pp., 2009.
De Beenhouwer, M., Aerts, R., and Honnay, O.: A global metaanalysis of the biodiversity and ecosystem service benefits of coffee and cacao agroforestry, Agr. Ecosyst. Environ., 175, 1-7, 2013.

De Deyn, G. B. and Van der Putten, W. H.: Linking aboveground and belowground diversity, Trends Ecol. Evol., 20, 625-633, doi:10.1016/j.tree.2005.08.009, 2005.

Derpsch, R., Friedrich, T., Kassam, A., and Li, H.: Current status of adoption of no-till farming in the world and some of its main benefits, International Journal of Agricultural and Biological Engineering, 3, 1-25, 2010.

De Schutter, O.: Agroecology and the Right to Food, Report presented at the 16th Session of the United Nations Human Rights Council, Geneva, Switzerland, United Nations Human Rights Council, 2011.

Desmet, P. J. J. and Govers, G.: A GIS procedure for automatically calculating the USLE LS factor on topographically complex landscape units, J. Soil Water Conserv., 51, 427-433, 1996.

Döll, P., Fiedler, K., and Zhang, J.: Global-scale analysis of river flow alterations due to water withdrawals and reservoirs, Hydrol. Earth Syst. Sci., 13, 2413-2432, doi:10.5194/hess-13-24132009, 2009.

Eagle, A. J., Henry, L. R., Olander, L. P., Haugen-Kozyra, K., Millar, N., and Robertson, G. P.: Greenhouse Gas Mitigation Potential of Agricultural Land Management in the United States: A syntesis of the literature, Nicholas Institute for Environmental Policy Solutions, Duke University, 2012.

Ellis-Jones, J. and Sims, B.: An appraisal of soil conservation technologies on hillside farms in Honduras, Mexico and Nicaragua, Project Appraisal, 10, 125-134, 1995.

FAO and ITPS: Status of the World's Soil Resources - Main Report, FAO and ITPS, 608 pp., 2015.

Gerland, P., Raftery, A. E., Ševčíková, H., Li, N., Gu, D., Spoorenberg, T., Alkema, L., Fosdick, B. K., Chunn, J., Lalic, N., Bay, G., Buettner, T., Heilig, G. K., and Wilmoth, J.: World population stabilization unlikely this century, Science, 346, 234-237, doi:10.1126/science.1257469, 2014.

Giller, K. E., Witter, E., Corbeels, M., and Tittonell, P.: Conservation agriculture and smallholder farming in Africa: The heretics' view, Field Crop. Res., 114, 23-34, doi:10.1016/j.fcr.2009.06.017, 2009.

Glaeser, E.: Triumph of the City: How Our Greatest Invention Makes Us Richer, Smarter, Greener, Healthier and Happier, Pan Macmillan, 2011.

Govers, G., Merckx, R., Van Oost, K., and van Wesemael, B.: Managing Soil Organic Carbon for Global Benefits: a STAP Technical Report, Global Environmental Facility, Washington, D.C., 70 pp., 2013.

Govers, G., Van Oost, K., and Wang, Z.: Scratching the Critical Zone: The Global Footprint of Agricultural Soil Erosion, Procedia Earth and Planetary Science, 10, 313-318, doi:10.1016/j.proeps.2014.08.023, 2014.

Grace, P. R., Antle, J., Aggarwal, P. K., Ogle, S., Paustian, K., and Basso, B.: Soil carbon sequestration and associated economic costs for farming systems of the Indo-Gangetic Plain: A meta-analysis, Agr. Ecosyst. Environ., 146, 137-146, doi:10.1016/j.agee.2011.10.019, 2012.

Harris, D. and Orr, A.: Is rainfed agriculture really a pathway from poverty?, Agr. Syst., 123, 84-96, 2014. 
Henao, J. and Baanante, C.: Agricultural production and soil nutrient mining in Africa: implications for resource conservation and policy development, IFDC-AN International Center for Soil Fertility and Agricultural Development, 2006.

Hiederer, R. and Köchyl, M.: Global soil organic carbon estimates and the harmonized world soil database, Luxembourg EUR 25225EN, 79 pp., 2012.

Hornbeck, R.: The enduring impact of the American dust bowl: Short-and long-run adjustments to environmental catastrophe, The American Economic Review, 1477-1507, 2012.

Imwangana, F. M., Vandecasteele, I., Trefois, P., Ozer, P., and Moeyersons, J.: The origin and control of mega-gullies in Kinshasa (DR Congo), Catena, 125, 38-49, 2015.

Janosky, J. S., Young, D. L., and Schillinger, W. F.: Economics of conservation tillage in a wheat-fallow rotation, Agron. J., 94, 527-531, 2002.

Johnson, L. C.: Soil loss tolerance: Fact or myth, J. Soil Water Conserv., 42, 155-160, 1987.

Keating, B. A., Carberry, P. S., Bindraban, P. S., Asseng, S., Meinke, H., and Dixon, J.: Eco-efficient agriculture: Concepts, challenges, and opportunities, Crop Science, 50, S-109-S-119, doi:10.2135/cropsci2009.10.0594, 2010.

Knowler, D. and Bradshaw, B.: Farmers' adoption of conservation agriculture: A review and synthesis of recent research, Food Policy, 32, 25-48, doi:10.1016/j.foodpol.2006.01.003, 2007.

Knowler, D., Bradshaw, B., and Gordon, D.: The economics of conservation agriculture, Land and Water Division, FAO, Rome, 2001.

Kok, H., Papendick, R., and Saxton, K. E.: STEEP: Impact of long-term conservation farming research and education in $\mathrm{Pa}$ cific Northwest wheatlands, J. Soil Water Conserv., 64, 253-264, 2009.

Krajick, K.: Green farming by the Incas?, Science, 281, 322-322, 1998.

Lahmar, R.: Adoption of conservation agriculture in Europe: lessons of the KASSA project, Land Use Policy, 27, 4-10, 2010.

Lassaletta, L., Billen, G., Grizzetti, B., Anglade, J., and Garnier, J.: 50 year trends in nitrogen use efficiency of world cropping systems: the relationship between yield and nitrogen input to cropland, Environ. Res. Lett., 9, 105011, doi:10.1088/17489326/9/10/105011, 2014.

Le Quere, C., Raupach, M. R., Canadell, J. G., Marland, G., Bopp, L., Ciais, P., Conway, T. J., Doney, S. C., Feely, R. A., Foster, P., Friedlingstein, P., Gurney, K., Houghton, R. A., House, J. I., Huntingford, C., Levy, P. E., Lomas, M. R., Majkut, J., Metzl, N., Ometto, J. P., Peters, G. P., Prentice, I. C., Randerson, J. T., Running, S. W., Sarmiento, J. L., Schuster, U., Sitch, S., Takahashi, T., Viovy, N., van der Werf, G. R., and Woodward, F. I.: Trends in the sources and sinks of carbon dioxide, Nat. Geosci., 2, 831-836, doi:10.1038/ngeo689, 2009.

Leys, A., Govers, G., Gillijns, K., Berckmoes, E., and Takken, I.: Scale effects on runoff and erosion losses from arable land under conservation and conventional tillage: The role of residue cover, J. Hydrol., 390, 143-154, doi:10.1016/j.jhydrol.2010.06.034, 2010.

Lilin, C.: Histoire de la restauration des terrains en montagne au 19ème siècle, Cahiers ORSTOM, Série Pédologie, 22, 139-145, 1986.
Lu, C. H. and van Ittersum, M. K.: A trade-off analysis of policy objectives for Ansai, the Loess Plateau of China, Agr. Ecosyst. Environ., 102, 235-246, doi:10.1016/j.agee.2003.09.023, 2004.

Lutz, W. and Kc, S.: Dimensions of global population projections: what do we know about future population trends and structures?, Philos. T. R. Soc. B, 365, 2779-2791, doi:10.1098/rstb.2010.0133, 2010.

Mader, P., Fliessbach, A., Dubois, D., Gunst, L., Fried, P., and Niggli, U.: Soil fertility and biodiversity in organic farming, Science, 296, 1694-1697, doi:10.1126/science.1071148, 2002.

Mekuria, W., Veldkamp, E., Haile, M., Nyssen, J., Muys, B., and Gebrehiwot, K.: Effectiveness of exclosures to restore degraded soils as a result of overgrazing in Tigray, Ethiopia, J. Arid Environ., 69, 270-284, doi:10.1016/j.jaridenv.2006.10.009, 2007.

Minasny, B., McBratney, A., Hong, S. Y., Sulaeman, Y., Kim, M. S., Zhang, Y. S., Kim, Y. H., and Han, K. H.: Continuous rice cropping has been sequestering carbon in soils in Java and South Korea for the past 30 years, Global Biogeochem. Cy., 26, 1-8, doi:10.1029/2012GB004406, 2012.

Montgomery, D. R.: Soil erosion and agricultural sustainability, P. Natl. Acad. Sci. USA, 104, 13268-13272, doi:10.1073/pnas.0611508104, 2007.

Mueller, N. D., Gerber, J. S., Johnston, M., Ray, D. K., Ramankutty, N., and Foley, J. A.: Closing yield gaps through nutrient and water management, Nature, 490, 254-257, 2012.

Napier, T. L., Boardman, J., Foster, I., and Dearing, J.: The evolution of US soil-conservation policy: from voluntary adoption to coercion, Soil erosion on agricultural land, Proceedings of a workshop sponsored by the British Geomorphological Research Group, Coventry, UK, January 1989, 627-644, 1990.

Nearing, M. A.: A single, continuous function for slope steepness influence on soil loss, Soil Sci. Soc. Am. J., 61, 917-919, 1997.

Neumann, K., Verburg, P. H., Stehfest, E., and Müller, C.: The yield gap of global grain production: A spatial analysis, Agr. Syst., 103, 316-326, 2010.

NRCS: 2007 National Resources Inventory - Soil Erosion on Cropland, 29, 2010.

Nyssen, J., Poesen, J., Gebremichael, D., Vancampenhout, K., D'Aes, M., Yihdego, G., Govers, G., Leirs, H., Moeyersons, J., Naudts, J., Haregeweyn, N., Haile, M., and Deckers, J.: Interdisciplinary on-site evaluation of stone bunds to control soil erosion on cropland in Northern Ethiopia, Soil Till. Res., 94, 151-163, doi:10.1016/j.still.2006.07.011, 2007.

Nyssen, J., Clymans, W., Poesen, J., Vandecasteele, I., De Raets, S., Haregeweyn, N., Naudts, J., Hadera, A., Moeyersons, J., Haile, M., and Deckers, J.: How soil conservation affects the catchment sediment budget - a comprehensive study in the north Ethiopian highlands, Earth Surf. Proc. Land., 34, 1216-1233, doi:10.1002/Esp.1805, 2009.

Oorts, K., Bossuyt, H., Labreuche, J., Merckx, R., and Nicolardot, B.: Carbon and nitrogen stocks in relation to organic matter fractions, aggregation and pore size distribution in no-tillage and conventional tillage in northern France, Eur. J. Soil Sci., 58, 248-259, doi:10.1111/j.1365-2389.2006.00832.x, 2007.

Ostrom, E.: A general framework for analyzing sustainability of social-ecological systems, Science, 325, 419-422, doi:10.1126/science.1172133, 2009. 
Peiretti, R. and Dumanski, J.: The transformation of agriculture in Argentina through soil conservation, Int. Soil Water Conserv. Res., 2, 14-20, doi:10.1016/S2095-6339(15)30010-1, 2014.

Perlman, J. E.: The metamorphosis of marginality: four generations in the favelas of Rio de Janeiro, Ann. Am. Acad. Polit. SS., 606, 154-177, 2006

Phalan, B., Balmford, A., Green, R. E., and Scharlemann, J. R. P. W.: Minimising the harm to biodiversity of producing more food globally, Food Policy, 36, S62-S71, 2011a.

Phalan, B., Onial, M., Balmford, A., and Green, R. E.: Reconciling food production and biodiversity conservation: Land sharing and land sparing compared, Science, 333, 1289-1291, doi:10.1126/science.1208742, 2011 b.

Pittelkow, C. M., Linquist, B. A., Lundy, M. E., Liang, X., Van Groenigen, K. J., Lee, J., Van Gestel, N., Six, J., Venterea, R. T., and Van Kessel, C.: When does no-till yield more? A global meta-analysis, Field Crop. Res., 183, 156-168, 2015.

Poeplau, C., Don, A., Vesterdal, L., Leifeld, J., Van Wesemael, B., Schumacher, J., and Gensior, A.: Temporal dynamics of soil organic carbon after land-use change in the temperate zone - carbon response functions as a model approach, Glob. Change Biol., 17, 2415-2427, doi:10.1111/j.1365-2486.2011.02408.x, 2011.

Poesen, J., Nachtergaele, J., Verstraeten, G., and Valentin, C.: Gully erosion and environmental change: importance and research needs, Catena, 50, 91-133, 2003.

Posthumus, H. and Stroosnijder, L.: To terrace or not: the short-term impact of bench terraces on soil properties and crop response in the Peruvian Andes, Environment, Development and Sustainability, 12, 263-276, 2010.

Quang, D. V., Schreinemachers, P., and Berger, T.: Ex-ante assessment of soil conservation methods in the uplands of Vietnam: An agent-based modeling approach, Agr. Syst., 123, 108-119, doi:10.1016/j.agsy.2013.10.002, 2014.

Quinton, J. N., Govers, G., Van Oost, K., and Bardgett, R. D.: The impact of agricultural soil erosion on biogeochemical cycling, Nat. Geosci., 3, 311-314, doi:10.1038/Ngeo838, 2010.

Ramachandran Nair, P. K., Mohan Kumar, B., and Nair, V. D.: Agroforestry as a strategy for carbon sequestration, J. Plant Nutr. Soil Sci., 172, 10-23, doi:10.1002/jpln.200800030, 2009.

Ramankutty, N., Evan, A. T., Monfreda, C., and Foley, J. A.: Farming the planet: 1. Geographic distribution of global agricultural lands in the year 2000, Global Biogeochem. Cy., 22, GB1003, doi:10.1029/2007GB002952, 2008.

Rijsdijk, A., Bruijnzeel, L. A. S., and Sutoto, C. K.: Runoff and sediment yield from rural roads, trails and settlements in the upper Konto catchment, East Java, Indonesia, Geomorphology, 87, 28-37, doi:10.1016/j.geomorph.2006.06.040, 2007.

Robb, G.: The discovery of France, Pan Macmillan, 2008.

Rockström, J., Lannerstad, M., and Falkenmark, M.: Assessing the water challenge of a new green revolution in developing countries, P. Natl. Acad. Sci. USA, 104, 6253-6260, doi:10.1073/pnas.0605739104, 2007.

Sanchez, P. A.: Tripling crop yields in tropical Africa, Nat. Geosci., 3, 299-300, 2010.

Sattari, S. Z., Bouwman, A. F., Giller, K. E., and van Ittersum, M. K.: Residual soil phosphorus as the missing piece in the global phosphorus crisis puzzle, P. Natl. Acad. Sci. USA, 109, 63486353, 2012.
Saunders, D.: Arrival City: How the Largest Migration in History Is Reshaping Our World, Knopf Doubleday Publishing Group, 2011.

Schneider, M. K., Lüscher, G., Jeanneret, P., Arndorfer, M., Ammari, Y., Bailey, D., Balázs, K., Báldi, A., Choisis, J.-P., and Dennis, P.: Gains to species diversity in organically farmed fields are not propagated at the farm level, Nat. Commun., 5, 4151, doi:10.1038/ncomms5151, 2014.

Sendzimir, J., Reij, C. P., and Magnuszewski, P.: Rebuilding resilience in the Sahel: regreening in the Maradi and Zinder regions of Niger, Ecol. Soc., 16, 1, doi:10.5751/ES-04198-160301, 2011.

Smaling, E. M. A., Stoorvogel, J. J., and Windmeijer, P. N.: Calculating soil nutrient balances in Africa at different scales, Fert. Res., 35, 237-250, doi:10.1007/bf00750642, 1993.

Sterk, G.: Causes, consequences and control of wind erosion in Sahelian Africa: a review, Land Degrad. Dev., 14, 95-108, 2003.

Stockmann, U., Minasny, B., and McBratney, A. B.: How fast does soil grow?, Geoderma, 216, 48-61, 2014.

Stone, J. R., Gilliam, J. W., Cassel, D. K., Daniels, R. B., Nelson, L. A., and Kleiss, H. J.: Effect of erosion and landscape position on the productivity of Piedmont soils, Soil Sci. Soc. Am. J., 49, 987-991, 1985.

Tiffen, M., Mortimore, M., and Gichuki, F.: More People, Less Erosion: Environmental Recovery in Kenya, John Wiley \& Sons Ltd, 1994.

Tilman, D., Balzer, C., Hill, J., and Befort, B. L.: Global food demand and the sustainable intensification of agriculture, P. Natl. Acad. Sci. USA, 108, 20260-20264, doi:10.1073/pnas.1116437108, 2011.

Torri, D. and Poesen, J.: Predictability and uncertainty of the soil erodibility factor using a global dataset, Catena, 31, 1-22, 1997.

Twomlow, S., Rohrbach, D., Dimes, J., Rusike, J., Mupangwa, W., Ncube, B., Hove, L., Moyo, M., Mashingaidze, N., and Mahposa, P.: Micro-dosing as a pathway to Africa's Green Revolution: evidence from broad-scale on-farm trials, Nutr. Cycl. Agroecosys., 88, 3-15, 2010.

United Nations: World Urbanization Prospects 2014: Highlights, United Nations Publications, 2014.

Valentin, C., Agus, F., Alamban, R., Boosaner, A., Bricquet, J.-P., Chaplot, V., De Guzman, T., De Rouw, A., Janeau, J.-L., and Orange, D.: Runoff and sediment losses from 27 upland catchments in Southeast Asia: Impact of rapid land use changes and conservation practices, Agr. Ecosyst. Environ., 128, 225-238, 2008.

Vanacker, V., Molina, A., Govers, G., Poesen, J., and Deckers, J.: Spatial variation of suspended sediment concentrations in a tropical Andean river system: The Paute River, southern Ecuador, Geomorphology, 87, 53-67, doi:10.1016/j.geomorph.2006.06.042, 2007a.

Vanacker, V., von Blanckenburg, F., Govers, G., Molina, A., Poesen, J., Deckers, J., and Kubik, P.: Restoring dense vegetation can slow mountain erosion to near natural benchmark levels, Geology, 35, 303-306, doi:10.1130/G23109a.1, 2007b.

VandenBygaart A. J., Bremer, E., McConkey, B. G., Janzen, H. H., Angers, D. A., Carter, M. R., Drury, C. F., Lafond, G. P., and McKenzie, R. H.: Soil organic carbon stocks on long-term agroecosystem experiments in Canada, Can. J. Soil Sci., 90, 543-550, doi:10.4141/cjss10028, 2010.

Van den Putte, A., Govers, G., Diels, J., Gillijns, K., and Demuzere, M.: Assessing the effect of soil tillage on crop 
growth: A meta-regression analysis on European crop yields under conservation agriculture, Eur. J. Agron., 33, 231-241, doi:10.1016/j.eja.2010.05.008, 2010.

Van Oost, K., Quine, T. A., Govers, G., De Gryze, S., Six, J., Harden, J. W., Ritchie, J. C., McCarty, G. W., Heckrath, G., Kosmas, C., Giraldez, J. V., da Silva, J. R. M., and Merckx, R.: The impact of agricultural soil erosion on the global carbon cycle, Science, 318, 626-629, doi:10.1126/science.1145724, 2007.

Van Rompaey, A. J. J., Govers, G., Van Hecke, E., and Jacobs, K.: The impacts of land use policy on the soil erosion risk: a case study in central Belgium, Agr. Ecosyst. Environ., 83, 8394, 2001.

Van Rompaey, A. J. J., Govers, G., and Puttemans, C.: Modelling land use changes and their impact on soil erosion and sediment supply to rivers, Earth Surf. Proc. Land., 27, 481-494, doi:10.1002/Esp.335, 2002.

Verbruggen, E., Roling, W. F. M., Gamper, H. A., Kowalchuk, G. A., Verhoef, H. A., and van der Heijden, M. G. A.: Positive effects of organic farming on below-ground mutualists: largescale comparison of mycorrhizal fungal communities in agricultural soils, New Phytol., 186, 968-979, doi:10.1111/j.14698137.2010.03230.x, 2010.
Verheijen, F. G., Jones, R. J., Rickson, R., and Smith, C.: Tolerable versus actual soil erosion rates in Europe, Earth-Sci. Rev., 94, 23-38, 2009.

Yang, D. W., Kanae, S., Oki, T., Koike, T., and Musiake, K.: Global potential soil erosion with reference to land use and climate changes, Hydrol. Process., 17, 2913-2928, doi:10.1002/hyp.1441, 2003.

Zentner, R., McConkey, B., Campbell, C., Dyck, F., and Selles, F.: Economics of conservation tillage in the semiarid prairie, Can. J. Plant Sci., 76, 697-705, 1996.

Zhang, X., Davidson, E. A., Mauzerall, D. L., Searchinger, T. D., Dumas, P., and Shen, Y.: Managing nitrogen for sustainable development, Nature, 528, 51-59, doi:10.1038/nature15743, 2015.

Zhao, J., Van Oost, K., Chen, L., and Govers, G.: Moderate topsoil erosion rates constrain the magnitude of the erosion-induced carbon sink and agricultural productivity losses on the Chinese Loess Plateau, Biogeosciences, 13, 4735-4750, doi:10.5194/bg13-4735-2016, 2016. 